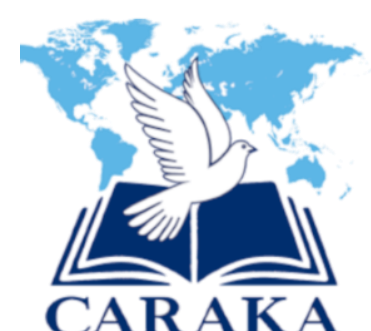

\begin{tabular}{|l|l|l|}
\hline Diserahkan: 17 Juni 2020 & Diterima: 16 Agustus 2020 & Diterbitkan: 12 Oktober 2020
\end{tabular}

\title{
UPAYA MENJAGA KESEIMBANGAN PEKERJAAN DENGAN KELUARGA
}

\author{
Purim Marbun \\ Sekolah Tinggi Teologi Bethel Indonesia \\ marbunpurim@gmail.com
}

\begin{abstract}
This research has motivated by the fact in the field that to balance the job and the family is problem of the most people today, especially of the servant of God (pastor, priest, lecturers, etc). The are faced with the choice of priority between family and work. Research by Keene and Quadgno's explain that 60\% of working adults find it difficult to achieve work balance with the family. The research method used to discuss this topic is a qualitative research study with a literature study approach by discussing various literatures related to the research topic. The researcher read, analyzed and found the issues that caused the imbalance between work and family. The final results of this study after alternatives and strategies to balance job with family life.
\end{abstract}

Keywords: Job; Family; Balance

\begin{abstract}
Abstrak
Penelitian ini dilatarbelakangi fakta di lapangan bahwa keseimbangan pekerjaan dengan kehidupan keluarga merupakan persoalan mayoritas masyarakat masa kini secara khusus para hamba Tuhan (pendeta, gembala, dosen, dll). Mereka diperhadapkan pada pilihan mengutamakan keluarga atau pekerjaan. Penelitian Keene dan Quadagno menyebutkan bahwa $60 \%$ orang dewasa yang bekerja sulit mencapai keseimbangan pekerjaan dengan keluarga. Metode penelitian yang digunakan membahas topik ini ialah studi penelitian kualitatif dengan pendekatan studi pustaka dengan membahas berbagai literatur terkait dengan topik penelitian. Peneliti membaca dan menganalisis serta menemukan masalah penyebab ketidakseimbangan pekerjaan dengan keluarga. Hasil akhir dari penelitian ini menawarkan strategi dan upaya menyelaraskan pekerjaan dengan waktu bersama keluarga.
\end{abstract}

Kata Kunci: Pekerjaan; Keluarga; Keseimbangan

\section{PENDAHULUAN}

Kehidupan yang kompleks di era milenial ini mengharuskan setiap pribadi mampu mengelola relasi yang seimbang antara waktu bekerja dengan kebersamaan dalam keluarga. Pekerjaan sering menyebabkan sebagian orang tidak memiliki ruang dan kesempatan bersama anak-anak dan keluarga. Oleh karena tuntutan tugas para pekerja aktif sering meninggalkan 
keluarga, misalnya urusan kantor, perjalanan dinas, dan tugas luar kota. Secara khusus bagi mereka yang tinggal perkotaan salah satu dampak pekerjaan yang menyita waktu mengakibatkan minimnya kesempatan untuk bersama-sama di keluarga. Minimnya waktu ini dipengaruhi lama bekerja di kantor, jarak rumah dengan kantor memakan waktu relatif lama, demikian juga kemacetan di jalan.

Handayani dalam penelitiaannya menjelaskan bahwa persoalan keseimbangan pekerjaan dengan keluarga terutama dialami oleh kaum perempuan. Data penelitiannya menyebutkan perempuan memiliki fungsi ganda, sebagai pekerja dan ibu rumah tangga, hal ini sangat mempengaruhi keseimbangan dalam pekerjaan. ${ }^{1}$ Dengan posisi sebagai ibu rumah tangga dan pekerja profesional, perempuan sering diperhadapkan dengan pengelolaan waktu. Hal ini mempengaruhi produktivitas kerja dan relasi harmonis dengan keluarga. Gambaran yang sama dijelaskan oleh Hairina dan Fahdhila bahwa peran ganda yang dikenakan kepada wanita yang telah berkeluarga cenderung mengakibatkan adanya work conflict ketika mereka tidak mampu menata dan mengelola tugas dan tanggung jawab dengan baik. ${ }^{2}$

Mayasari menyebutkan bahwa ketidakseimbangan pekerjaan dengan keluarga dipengaruhi adanya faktor tekanan dalam pekerjaan. Konflik pekerjaan dan keluarga menyumbang tekanan bagi individu yang bekerja. Hasil penelitiannya membuktikan bahwa konflik pekerjaan dan keluarga khusus bagi dosen wanita menimbulkan tekanan, yang pada akhirnya mengakibatkan kerja tidak produktif. ${ }^{3}$ Keene \& Quadagno mendukung data di atas, dengan menyebutkan bahwa $60 \%$ orang dewasa yang bekerja sulit mencapai waktu bersama khususnya pasangan suami istri. Dalam penelitian tersebut dijelaskan bahwa pasangan suami isteri bekerja memiliki potensi yang kontras mengalami relasi yang terganggu seperti disharmoni menyangkut kepentingan pekerjaan kantor atau rumah. ${ }^{4}$ Penelitian lain, Sugiarti menjelaskan bahwa salah satu penyebab kepuasan kerja dan work balance adalah adanya penerimaan lingkungan kerja (teman-teman sesama karyawan) yang menerima kehadiran seorang pekerja dengan terbuka. Lingkungan yang terbuka dan saling membantu akan memberikan kontribusi yang positif bagi keseimbangan pekerjaan dengan keluarga. ${ }^{5}$ Manggaharti dan Noviati menjelaskan bahwa ada hubungan positif dan signifikan antara dukungan sosial dengan keseimbangan kerja yang melahirkan produktivitas yang baik. ${ }^{6}$

\footnotetext{
${ }^{1}$ Arri Handayani, "Keseimbangan Kerja Keluarga Pada Perempuan Bekerja: Tinjauan Teori Border," Bulletin Psikologi 21, No. 2 (2012): 90.

${ }^{2}$ Yulia Hairina and Mahdia Fadhila, "Strategi Work-Family Balance Pada Perempuan Suku Banjar Yang Memiliki Peran Ganda,” Jurnal Studia Insania, Vol6, No. 2 (2019): 184.

${ }^{3}$ N M D A Mayasari, "Efek Moderasi Dukungan Sosial Dalam Hubungan Konflik Pekerjaan Keluarga Dengan Stres Kerja Dosen Wanita Di Fakultas Ekonomi Undiksha,” Jurnal Manajemen Vol 6, No. 1 (2020): 1.

${ }^{4}$ Handayani, "Keseimbangan Kerja Keluarga Pada Perempuan Bekerja: Tinjauan Teori Border."

5 Thalia Febiola Putri and Yenny Sugiarti, "Work-Life Balance Konsultan Pajak Di Kantor Konsultan 'X' Di Surabaya,” Jurnal Akuntansi dan Teknologi Informasi Vol 3, No. 1 (2020): 1.

${ }^{6}$ Retno Manggaharti and Nur Pratiwi Noviati, "Keseimbangan Kehidupan Kerja Ditinjau Dari 165 | Copyright $\odot$ 2020, CARAKA, ISSN 2722-1407 (Cetak), 2722-1393 (Online)
} 
Dalam pengamatan peneliti secara khusus di lingkungan pelayanan (gereja dan sekolah) hal yang serupa juga muncul bagi keluarga hamba Tuhan. Demi pekerjaan dan pelayanan kehidupan keluarga dilalaikan, bahkan sering terjadi atas nama pelayanan seperti jadwal-jadwal khotbah, pelayanan konseling, seminar, dll keluarga mengalami dampaknya. Salah satu satu imbasnya ialah relasi dengan anak, isteri atau suami tidak terbangun dengan intens, kualitas komunikasi dengan anggota keluarga tidak efektif, dan kadang demi mengejar prestise pelayanan, keluarga diabaikan.

Berdasarkan uraian di atas fokus penelitian dalam tulisan ini berupaya menemukan langkah-langkah praktis sebagai strategi membangun keseimbangan pekerjaan dan keluarga bagi hamba Tuhan (dosen, pendeta, gembala). Diharapkan strategi yang ditawarkan mampu menolong hamba Tuhan mengimplementasikan keseimbangan kerja dengan keluarga demi berlangsungkan harnomi kehidupan yang lebih baik.

\section{METODE PENELITIAN}

Penelitian ini didasarkan pada metode kualitatif dengan pendekatan studi pustaka. studi pustaka merupakan teknik pengumpulan data dengan cara studi terhadap sumber literatur yang berhubungan dengan masalah yang dibahas. ${ }^{7}$ Peneliti akan mengkaji berbagai literatur terkait dengan topik bahasan dan menganalisis dengan komprehensif. ${ }^{8}$ Analisis deskriptif ${ }^{9}$ dipakai untuk menganalisis dan menemukan konsep-konsep strategi menyeimbangkan pekerjaan dan keluarga.

\section{HASIL DANPEMBAHASAN}

\section{Memahami Tentang Keluarga}

Keluarga ialah unit terkecil dari kelompok masyarakat, ini merupakan konsep yang sudah lazim dipahami. Keluarga dalam konteks masyarakat yang besar selalu dipahami sebagai pembentuk adanya masyakat. Hilderd Geertz seperti dikutip oleh N,K Atmaja Hadinoto mengatakan :"The family in any society, is the bridge between the individual and his culture”. Sebagai unit kelompok sosial yang inti di masyarakat, keluarga memiliki peran dan tugas menyiapkan anggotanya untuk mempu hidup sebagai kelompok sosial dengan masyarakat sekelilingnya. ${ }^{10}$ Tugas mendasar dari keluarga dalam hal ini yakni memberi

\footnotetext{
Dukungan Sosial Pada Pekerja,” Jurnal Studia Insania Vol 7, No. 1 (2019): 1.

${ }^{7}$ Dicky Dominggus, "Pengabdian Abdi Dalem Keraton Yogyakarta Sebagai Potret Pelayanan Masa Kini," Voice of Hami 2, No. 2 (2020): 81.

${ }^{8}$ Sugiyono, Metode Penelitian Kualitatif (Bandung: Alfabeta, 2009), 13.

${ }^{9}$ Lexy L Moleong, Metode Penelitian Kualitatif (Bandung: PT Remaja Rosdakarya, 2004), 27.

${ }^{10}$ N K Atmaja Hadinoto, Dialog Dan Edukasi Agama Kristen Dalam Masyarakat Indonesia (Jakarta:
} BPK Gunung Mulia, 2012), 12. 
pemahaman bahwa keluarga adalah bagian dari masyarakat besar. Keluarga tidak bisa menutup diri dengan dunia sekelilingnya.

Lahirnya keluarga dalam hal ini pasangan suami isteri pada dasarnya dilandasi cinta kasih. Pria dan wanita terikat dengan, lembaga pernikahan sejatinya didasari Firman Tuhan (Kej 1:28-30; Matius 19:4-6). Perjanjian Lama melaporkan bahwa cinta kasih adalah landasan utama pembentukan keluarga. ${ }^{11}$ Wujud dari cinta kasih yang dihidupi suami isteri tentu didasarkan pada cinta kasih Allah. Suami dan isteri mempraktekkannya melalui perilaku saling menghargai, menerima, dan juga mengampuni.

Secara konseptual istilah keluarga dipahami menjelaskan mereka yang telah menikah. Pemahaman ini berkembang menjadi pasangan pernikahan yang memiliki anak. Tidak semua pernikahan dikaruniai anak, ada juga pasangan suami isteri sengaja menunda memiliki anak atau bahkan tidak ingin memiliki anak. Faktor-faktor ini mempengaruhi konsep dan pemahaman tentang keluarga menjadi berubah.

Alkitab menjelaskan bahwa keluarga ialah suami isteri yang telah dipersatukan dalam pernikahan yang Kudus. Kejadian 1:26-28 menegaskan bahwa ide dan gagasan tentang lahirnya keluarga berasal dari Tuhan. Allah yang merencanakan, menggagas bahkan mewujudkan melalui penciptaan laki-laki dan perempuan yang kemudian dipersatukan dalam pernikahan yang kudus. Keluarga adalah maha karya Tuhan yang spesial, tidak boleh ada upaya untuk merusaknya dengan melakukan perceraian di antara suami dan isteri. Tuhan tidak hanya menciptakan keluarga, namun juga memberikan mandat ilahi yakni beranak cucu dan bertambah banyak dan menguasai bumi. Tugas ini dipahami sebagai mandat ilahi pembangunan dan pengembangan generasi.

Dalam Injil Matius 19:5-6, dijelaskan proses pembentukan keluarga dengan mempersatukan laki-laki dan perempuan. Laki-laki meninggalkan ayah dan ibunya dan bersatu dengan isterinya, dan mereka menjadi satu daging. Dalam perspektif Injil Matius maka ditemukan tiga prinsip pembangunan keluarga, pertama kemandirian. Teks kalimat yang menyebutkan "meninggalkan ayah dan ibunya" ini memberikan penjelasan bahwa anak-anak telah dewasa dan mandiri. Kedua, prinsip kesatuan. Dengan bersatunya laki-laki dengan isterinya hal ini menggarkan keutuhan dan kesatuan, itulah sebabnya pernikahan kristen melarang terjadi perceraian. Ketiga, kedewasaan. Tidak ada pernikahan yang mampu membentuk keluarga jika tidak memiliki kedewasaan, diantaranya dewasa secara usia dan berpikir.

Keluarga memiliki tugas dan tangung jawab mendidik anak-anak. Tanggunng jawab bukan hanya mencukupi kebutuhan secara jasmani tetapi rohani. Pemenuhan kebutuhan

${ }^{11}$ Rachel Iwamony, “Cinta Kasih Sebagai Dasar Hidup Keluarga,” Tifa Teologi: Jurnal Pascasarjana Teologi Universitas Kristen Indonesia Maluku Vol 3, No. 1 (2014): 45. 
jasmani dilakukan dengan menyediakan sandang, pangan dan papan. Keluarga dalam hal ini orangtua wajib memenuhi itu bagi anak-anaknya. Pemenuhan kebutuhan rohani dilakukan dengan cara mendidik, mengajar, membina, mengarahkan seluruh perilaku dan kararter anakanak. Salah satu metode yang baik membangun karakter yakni orangtua memberikan teladan.

Keluarga adalah lembaga yang bertanggung jawab untuk pendidikan rohani anakanak, hal ini tidak boleh diabaikan. Dalam kitab Ulangan 6:4-9, keluarga diberi mandat mengajar dan membina anak-anak. Pengajaran dilakukan di rumah, pada waktu duduk, berbaring dan juga dalam perjalanan. Tari dan Taofano menjelaskan bahwa pendidikan anak adalah tanggung jawab orang tua. Orang tua melakukannya dengan pola asuh yang baik dan benar. Pendidikan di sekolah bukanlah yang utama dalam pendidikan anak-anak, melainkan keluarga. ${ }^{12}$

N.K. Atmaja menjelaskan di Indonesia keluarga-keluarga masih memiliki asumsi bahwa mendidik anak dapat dilakukan secara instan dan otomatis, pada hal dibutuhkan proses yang panjang dalam mendidik anak-anak. Kesalahan keluarga salah satunya ialah mempercayakan pendidikan anak kepada orang yang paling tua di keluarga, atau juga mempercayakan kepada kakek dan nenek. Keluarga besar (extended family) memang memiliki persoalan yang lebih kompleks itulah sebabnya urusan mendidik anak sering menjadi tanggung jawab kakek dan nenek, fakta dan data ini masih ditemukan di zaman ini. ${ }^{13}$

Pergeseran nilai dan pemahaman tentang keluarga semakin nyata pada zaman ini, khusus bagi mereka yang tinggal di kota, derasnya pengaruh globalisasi cenderung mengubah pola hidup keluarga. Salah satu pergeseran yang terjadi tentang eksistensi waktu dalam keluarga. Pemanfaatan waktu di rumah sangat minim dan terbatas karena urusan pekerjaan. Tuntutan pekerjaan kantor, posisi dan tanggung jawab di market place bahkan pelayanan gereja merubah tatanan dan pola hidup keluarga. Potret ini bisa dilihat pada berbagai aktivitas dari waktu-waktu yang dimiliki anggita keluarga.

Conger \& Conger seperti dikutip oleh Handayani menjelaskan deskripsi posisi pekerjaan yang diemban para wanita turut juga mempengaruhi tatanan hidup dalam keluarga. Jika dulu dimaknai bekerja adalah tugas laki-laki, belakangan wanita justu banyak yang bekerja (wanita karier). Tentu hal ini mengubah postur perilaku dan posisi wanita yang bukan lagi sebagai ibu rumah tangga, melainkan sebagai pekerja aktif. Wanita pada akhirnya memainkan peran ganda, di satu sisi sebagai ibu rumah tangga namun di sisi lain seorang pekerja profesional. ${ }^{14}$

\footnotetext{
${ }^{12}$ Ezra Tari and Talizaro Tafonao, "Pendidikan Anak Dalam Keluarga Berdasarkan Kolose 3:21," Kurios: Jurnal Teologi dan Pendidikan Agama Kristen Vol 5, No. 1 (April 30, 2019): 25.

${ }^{13}$ Hadinoto, Dialog Dan Edukasi Agama Kristen Dalam Masyarakat Indonesia, 12.

${ }^{14}$ Handayani, "Keseimbangan Kerja Keluarga Pada Perempuan Bekerja: Tinjauan Teori Border", 90 
Kehidupan keluarga hamba Tuhan (pendeta, gembala, dosen) memiliki tugas dan fungsi yang beragam. Apalagi jika dihubungkan dengan tugas-tugas gereja dan kemasyarakatan, maka fungsi dan peran menjadi lebih luas. Dalam rangka melaksanakan tugas-tugas tersebut, hamba Tuhan didorong membuat pilihan yang tepat. Hamba Tuhan harus memhami diri sebagai alat Tuhan bagi gereja dan masyakat namun juga sebagai kepala rumah tangga, karena itu harus mampu menyeimbangkan peran dan fungsi secara tepat. Pelayanan pertama yang harus dilakukan hamba Tuhan yakni keluarga, selanjutnya jemaat dan masyarakat yang lebih luas.

Kitab Ulangan 6:4-9 menjelaskan tugas kepala keluarga kepada anak-anak mereka ialah mengajarkan firman Tuhan secara berulang-ulang, apabila mereka di rumah, dalam perjalanan, sedang berbaring dan dalam perjalanan. Hartono menjelaskan ada beberapa hal yang dapat dilakukan di keluarga dalam mendidik anak-anak antara lain: (1) memperkenalkan firman Tuhan sejak dini; (2) mengajarkan cara berdoa; (3) membiasakan beribadah kepada Tuhan; (4) memberikan teladan mengasihi; dan (5) mempraktekkan kasih. ${ }^{15}$ Jika memperhatikan fungsi-fungsi ini maka erat kaitannya dengan ketersediaan waktu yang dimiliki kepala keluarga di dalam rumah. Mereka akan mampu menjalankan tugas ini dengan baik jika secara tepat dan akurat memainkan peran di dalam rumah dan di luar rumah.

Pemahaman tentang keluarga dikembangkan oleh Lazlofly seperti dikutip Handayani menjelaskan tahapan-tahapan perkembangan yakni: keluarga inti (hanya sumi dan isteri), keluaga yang telah memiliki keturunan, keluarga yang memiliki anak usia prasekolah, keluarga yang telah menyekolahkan anak-anak, keluarga dengan anak remaja, keluarga dengan anak usia dewasa muda (sudah menikahkan anak-anak), orangtua masa pertengahan (tanpa jabatan) dan keluarga lanjut usia. ${ }^{16}$ Dari klasifikasi ini dapat diperhatikan bahwa masa-masa genting yang sangat membutuhkan waktu bagi keluarga terkait dengan hubungan pekerjaan dengan keluarga yakni pada tahapan keluarga pemula sampai melepas anak dewasa. Masa ini ditandai dengan kecenderungan memperjuangkan antara pekerjaan atau keluarga, hal ini menjadi sangat dilematis.

Berdasarkan paparan di atas disimpulkan bahwa keluarga ialah komunitas terkecil dari masyarakat yang dibentuk melalui pernikahan (suami, isteri), sebuah lembaga ilahi yang dibentuk Allah untuk melaksanakan tugas dan mandat mandat prokreasi beranak cucu dan bertambah banyak, serta memenuhi bumi untuk berkarya melalui pekerjaan baik di keluarga, gereja dan masyarakat.

\footnotetext{
${ }^{15}$ Handreas Hartono, "Membentuk Karakter Kristen Pada Anak Keluarga Kristen," KURIOS: Jurnal Teologi dan Pendidikan Agama Kristen Vol 2, No 1 (2014): 62.

${ }^{16}$ Handayani, "Keseimbangan Kerja Keluarga Pada Perempuan Bekerja: Tinjauan Teori Border," 90 169 | Copyright $@$ 2020, CARAKA, ISSN 2722-1407 (Cetak), 2722-1393 (Online)
} 


\section{Memahami Tentang Pekerjaan}

Pekerjaan (job) secara umum dipahami kegiatan atau aktivitas yang bertujuan untuk mendapatkan uang. Seseorang bekerja umumnya digerakkan motivasi mendapatkan uang (upah). Ini adalah tingkatan paling rendah motif seseorang mau bekerja. Pada tingkatan selanjutnya biasanya seseorang bekerja didorong oleh motif ingin mengembangkan talenta, kemampuan dan relasi. Sedikit jumlah orang yang dapat bekerja mencapai aktualiasi diri, karena menurut teori Abraham Maslow, seperti dikutip Adhani menjelaskan bahwa pola kerja dimulai dari level paling bawah yakni bekerja untuk pemenuhan kebutuhan dasar, barulah kemudian meningkat ke level berikutnya sampai kepada aktualisasi diri. ${ }^{17}$ Bagi hamba Tuhan pekerjaan harus dimaknai kesempatan dan peluang pengabdian serta menjadi berkat bagi banyak orang.

Pekerjaan merupakan hal yang potensial berkontribusi dalam perbaikan hidup dan taraf kualitas tertentu. Pekerjaan harus dilakukan dengan profesional untuk memberi dampak dan pengaruh yang signifikan. Salah satu wujud nyata pekerjaan dapat berdampak jika melalui pekerjaan tersebut ada nilai-nilai kesaksian yang diberikan. Ezra Tari dan Purnama Pasande menjelaskan bahwa pekerjaan bisa berdampak jika dilakukan dengan profesional yang ditandai dengan integritas, tanggung jawab, kerja dengan semangat, penuh pengabdian, kreatif dan rendah hati. ${ }^{18}$

Ditinjau dari sudut pentingnya pekerjaan untuk memenuhi kebutuhan keluarga, cenderung dimaknai untuk mendapatkan upah. Ini menjadi pandangan umum dari setiap orang yang bekerja. Agung Budianto dkk dalam deskripsi hasil penelitiaanya yang menjelaskan bahwa kompensasi berupa uang masih mendominasi dorongan kerja yang dilakukan sejumlah orang. Lebih lanjut dijelaskan bahwa kompensasi finansial berkorelasi positif dan signifikan bagi karyawan, dengan pemamaham ini kepuasan kerja dan hasil kerja didorong oleh uang yang mereka dapatkan. ${ }^{19}$

Faktor lain yang memberi pengaruh seseorang bekerja dengan baik adalah alasan psikologis dan sosiologis. Dimensi alasan psikologis berkaitan erat dengan status diri bukan pengangguran melainkan bekerja secara tetap, ini memberi nilai positif bagi pekerja aktif. Dimensi alasan sosiologis meliputi keberadaan dan relasi seorang yang bekerja dengan dunianya, ia bekerja untuk tujuan kemanfaatan bukan hanya pribadi tapi orang lain, misalnya

${ }^{17}$ Akbar Rizky Adhani, "Pengaruh Kebutuhan Aktualisasi Diri Dan Beban Kerja Terhadap Prestasi Kerja Karyawan,” Jurnal Ilmu Manajemen (JIM) Vol 1, No. 4, (2013): 1223.

18 Tari Ezra and Purnama Pasande, "Etika Kerja Profesional Berdasarkan 2 Kor 2:15-16," Jurnal Gamaliel: Teologi Praktika Vol 1, No. 2 (September 2019): 87.

${ }^{19}$ Agung Budianto, Yonathan Pongtuluran, and Syaharuddin Y, "Pengaruh Etika Kerja, Motivasi Kerja Dan Kompensasi Finansial Terhadap Kinerja Karyawan," Jurnal KINERJA Vol 14, No. 1 (January 9, 2018 ): 1. 170 | Copyright $@$ 2020, CARAKA, ISSN 2722-1407 (Cetak), 2722-1393 (Online) 
ia bekerja untuk membantu keluarga dan orang lain. Pada dimensi ini pekerjaan atau bekerja dianggap mampu menaikkan status sosial dan mendapat pengakuan dari orang lain.

Penelitian Handyani dkk, memberikan gambaran latar belakang yang mendorong bekerja antara lain: mendapatkan tambahan penghasilan, mengisi waktu luang, proses adaptasi dengan lingkungan sosial, namun ada juga karena terpaksa bekerja untuk kelangsungan hidup (masa depan dan keluarga), sebagai usaha mendapatkan modal usaha dan menunjukkan eksistensi diri. ${ }^{20}$ Keragaman faktor yang melatarbelakangi ini menunjukkan ada berbagai macam tipe manusia dalam kaitan pekerjaan. Faktor tersebut juga hendak menjelaskan motifmotif bekerja tidak sama pada semua bidang pekerjaan yang dilakukan.

Dari paparan di atas dapat disebutkan bahwa tujuan bekerja memenuhi kebutuhan dan pengembangan ekonomi keluarga. Pemenuhan kebutuhan sudah pasti berkaitan dengan sandang, pangan dan papan, sedangkan pengembangan ekonomi keluarga dapat dimaknai sebagai upaya meningkatkan taraf hidup dan juga peningkatan karir. Untuk membangun tujuan yang positif dan benar dibutuhkan kedewasaan menempatkan pekerjaan secara proporsional. Dalam perspektif kekristenan salah satu aspek yang menolong pemahaman tujuan pekerjaan semakin baik dan benar ialah memaknainya sebagai pengabdian dan ibadah kepada Tuhan.

Agar seseorang memiliki pemahaman dan pandangan yang baik terhadap pekerjaan, perlu memiliki kesiapan kerja yang baik. Salah satu kesiapan bekerja yang dimaksud yakni upaya mengaktualisasikan diri. Dalam konteks ini pekerjaan bukanlah untuk mencari uang semata, melainkan menemukan makna diri dan nilai hidup bagi orang lain. Handayani dkk mengungkapkan bahwa para ibu yang bekerja harus memaknainya sebagai tanggung jawab. Deskripsi penelitian menjelaskan ibu-ibu yang bekerja di luar rumah tetap bertanggung jawab mengerjakan tugas-tugas rumah tangga. ${ }^{21}$

Pemahaman yang perlu dikembangkan oleh hamba Tuhan (pendeta, gembala, dosen) harus menitikberatkan nilai pelayanan dan pengabdian kepada Tuhan. Para hamba Tuhan melayani bukan untuk mencari uang, kedudukan atau posisi melainkan mengabdikan diri kepada rencanaNya. Ezra Tari dan Purnama Pasande menegaskan bahwa pekerjaan harus menjadi alat keharuman bagi nama Tuhan. Orang Kristen yang bekerja terlebih para hamba Tuhan terpanggil melayani dan bekerja serta menjadi saksi bagi dunia ini. ${ }^{22}$

Oleh karena pekerjaan dimaknai sebagai pengabdian kepada Tuhan, maka fondasi yang paling kuat mendorong hamba Tuhan bekerja dan melayani adalah ialah panggilan. Panggilan

${ }^{20}$ Arri Handayani, Tina Afiati, and M G Adiyanti, Studi Eksplorasi Makna Keseimbangan Kerja Keluarga Pada Ibu Bekerja, 2015, 32.

21 Ibid.

${ }^{22}$ Ezra and Pasande, "Etika Kerja Profesional Berdasarkan 2 Kor 2:15-16", 87. 
niscaya akan mendorong hamba Tuhan bekerja sepenuh hati, bukan untuk keuntungan finansial. Kejadian 1:28-30 memberikan makna teologis pekerjaan sebagai anugerah Tuhan dimanfaatkan bagi kelangsungan hidup dan memuliakan Tuhan.

Ada dua mandat dalam pekerjaan yakni mandat ilahi dan mandat pembangunan. Disebut mandat ilahi karena pekerjaan berasal dari Tuhan, itu sebabnya pekerjaan adalah anugerah, dan sebagai anugerah semua pekerjaan harus digunakan untuk melayani Tuhan. ${ }^{23}$ Dalam kaitan mandat ilahi manusia pertama di Taman Eden mendapat perintah dari Tuhan mengusahakan taman bagi kehidupan. Dari pemahaman ini pekerjaan tidak mungkin dilakukan oleh manusia tanpa seizinkan Tuhan.

Pekerjaan sebagai mandat pembangunan bertujuan bagi pengembangan kehidupan manusia. Oleh karena tujuannya untuk pembangunan manusia maka Tuhan memberikan perintah untuk mengeksplorasi pekerjaan untuk kehidupan. Untuk dapat melakukan hal di atas dengan baik, paradigma bekerja khusus hamba-hamba Tuhan harus mengalami perubahan. Mereka tidak boleh memandang bahwa pekerjaan hanya untuk tujuan mencari keuntungan melainkan sebagai pelayanan dalam mengembangkan nilai-nilai kehidupan. Paradigma yang harus dikedepankan ialah bekerja harus mewujudkan karakter seperti Kristus, penuh kesungguhan dan tanggung jawab serta melakukannya dengan kreatif dan inovatif.

Pekerjaan (job) sebagai tugas pembangunan kehidupan dapat dimaknai bertujuan mentransformasikan manusia. Dalam konteks ini misi pekerjaan yakni membawa perubahan bagi setiap individu, baik perubahan taraf hidup maupun nilai-nilai yang dianut. Dalam Kisah Rasul 18 dijelaskan dalam rangka melakukan tugas-tugas misi, Paulus harus melakukan pekerjaan sebagai tukang kemah. Tugas ini dikerjakan secara professional tanpa mengesampingkan tugas utamanya untuk memberitakan Injil. ${ }^{24}$ Paulus memperlihatkan kepada pembaca Alkitab bahwa pekerjaan dan panggilan pelayanan, dapat berjalan seimbang tergantung penataan yang dilakukan masing-masing yang bekerja. Salah satu tujuan pekerjaan dalam hal ini membawa transformasi kehidupan maka harus direncanakan dengan baik, memiliki sasaran dan target yang terukur. Pekerjaan harus mampu mengantar setiap pribadi mengalami peningkatan nilai-nilai kehidupan bukan hanya bagi dirinya tetapi juga orang lain.

Berdasarkan paparan di atas dapat disimpulkan bahwa bekerja adalah mandat yang diberikan Tuhan kepada manusia, sekaligus anugerah bagi setiap pribadi yang harus direspon dengan cara yang baik dan benar. Pekerjaan pada prinsipnya dapat dijadikan sebagai sumber

${ }^{23}$ Jacky Latupeirissa, "Etika Bisnis Ditinjau Dari Perspektif Alkitab," PASCA : Jurnal Teologi dan Pendidikan Agama Kristen 15, no. 1 (November 30, 2019): 9.

${ }^{24}$ Junior Natan Silalahi, "Paulus Sang Entrepreneur: Pembuat Tenda Sebagai Jembatan Penginjilan," Visio Dei: Jurnal Teologi Kristen Vol 1, No. 1 (2019): 1. 
penghidupan bagi diri sendiri dan keluarga, namun tujuan lain yang lebih utama ialah mentransformasi kehidupan masyarakat.

\section{Keseimbangan Pekerjaan dan Keluarga}

Salah satu pemaknaan mendasar tentang keseimbangan pekerjaan dan keluarga yakni ketika ada waktu yang cukup bagi keluarga selain mengerjakan tugas-tugas di kantor. Clark seperti dikutip Handayani menyebutkan bahwa keselarasan kerja ditandai dengan tidak adanya konflik dalam keluarga yang disebabkan pekerjaan atau jika konflik ada hanya minum dan dapat diatasi. ${ }^{25}$ Lebih lanjut pemahaman yang dikembangkan bukan soal tidak adanya konflik namun juga berkaitan dengan apa hasil yang didapat dari pekerjaan tersebut.

Mark dan Grzywacz menyebutkan komponen yang mengindikasikan adanya keseimbangan pekerjaan dengan keluarga yaitu work family facilitation. ${ }^{26}$ Melalui pekerjaan setiap individu mampu menghasilkan fasilitas dan kebutuhan keluarga. Umumnya fasilitas yang dimaksud ialah mendapat tempat tinggal yang layak, mampu menyekolahkan anak, dan fasilitas lainnya.

Aspek-aspek lain keseimbangan kerja yakni pengaturan peran dan fungsi di dalam dan di luar rumah. Penataan fungsi-fungsi ini menjadi relevan dalam pengaturan waktu dan penyelesaian tugas. Mark dan MacDermind dikutip oleh Handayani dkk, menjelaskan konsep keseimbangan peran memberikan alternatif bagi setiap individu untuk memprioritaskan fungsi dan peran mana yang akan didahulukan. Dalam hal ini pun setiap individu mampu mengelola dan mengatur tanggung jawab. ${ }^{27}$

Paparan firman Tuhan mengenai keseimbangan kerja dan keluarga dilakukan dengan di menetapkan langkah-langkah yang akurat dan konkrit melaksanakan tugas bagi keluarga dan juga pekerjaan. Keluaran 34:21 dicatat, :"Enam harilah lamanya engkau bekerja, tetapi pada hari yang ketujuh haruslah engkau berhenti, dan dalam musim membajak dan musim menuai haruslah engkau memelihara hari perhentian juga.” Teks ini mengamanatkan bekerja memerlukan waktu istrirahat, manusia tidak seterusnya bekerja tanpa ada waktu istirahat. Jadi dalam teks ini terungkap bahwa hidup manusia harus memiliki keseimbangan antara bekerja dengan mengerjakan tugas. Dalam bagian teks lain disebutkan juga ada waktunya membajak namun akan datang waktu menuai, lebih lanjut disebutkan bahwa enam hari bekerja dan kemudian pada hari ketujuh beristirahat. Dalam ayat ini jelas terlihat keseimbangan bekerja

${ }^{25}$ Handayani, "Keseimbangan Kerja Keluarga Pada Perempuan Bekerja: Tinjauan Teori Border."

${ }^{26}$ J. G. Grzywacz and N. F. Marks, "Reconceptualizing the Work-Family Interface: An Ecological Perspective on the Correlates of Positive and Negative Spillover between Work and Family.," Journal of occupational health psychology Vol 5, No. 1 (2000): 127.

${ }^{27}$ Handayani, Afiati, and Adiyanti, Studi Eksplorasi Makna Keseimbangan Kerja Keluarga Pada Ibu Bekerja. 
dan pelaksanaan sabat. Ini memberikan anjuran dan dorongan setiap individu yang bekerja harus memperhatikan penggunaan waktu, hidup bekerja atau melayani seimbang dengan beribadah kepada Tuhan.

Pekerjaan atau pelayanan adalah bagian tak terpisahkan bagi hamba Tuhan (pendeta, gembala, dosen), ini merupakan panggilan sekaligus tanggung jawab dari Tuhan. Di sisi lain keluarga sebagai basis kehidupan hamba Tuhan memerlukan kehadiran mereka. Keluarga tidak boleh ditelantarkan demikian juga pekerjaan, dalam hal inilah penting mengupayakan keseimbangan pekerjaan (pelayanan) dengan kehidupan keluarga.

Berdasarkan penjelasan di atas disimpulkan esensi utama keseimbangan pekerjaan dengan keluarga ialah kemampuan setiap hamba Tuhan mengelola tugas, fungsi dan peran di rumah dan di luar rumah secara akurat sehingga kehidupan keluarga dan pekerjaan beriringan dengan baik dan efektif. Ukuran kondisi yang kondusif tersebutk yakni jika konflik dalam keluarga minim, tanggung jawab dilakukan dengan baik, peran dan fungsi dikerjakan membawa peningkatan nilai-nilai kehidupan.

\section{Strategi Keseimbangan Pekerjaan Dengan Keluarga}

Bagaimana cara membentuk keseimbangan keluarga dengan pekerjaan? Pertanyaan ini bukan semata-mata untuk dijawab secara teoritis melainkan secara praktis bagi kehidupan hamba Tuhan. Dalam menjelaskan hal ini ada tiga perspektif yang harus dipahami yakni etis teologis, psikologis dan manajemen. Tiga hal ini akan dijelaskan secara berurutan seperti di bawah ini.

Pada dimensi teologis kerangka melakukan keseimbangan pekerjaan dengan keluarga, pertama-tama harus dihubungkan dengan makna pekerjaan (pelayanan) tersebut. Dalam Perjanjian Baru istilah pelayanan dipakai kata leitourgia dari kata laos artinya orang dan ergon artinya kerja. Dalam Perjanjian Lama dipahami sebagai ibadah dengan istilah abodah dan sharath. Pemaknaanya sama dengan istilah di atas menunjuk kepada kerja. ${ }^{28}$ Berdasarkan penjelasan di atas pekerjaan harus dipakai sebagai pengabdian dan pelayanan kepada Tuhan, melalui tugas-tugas keseharian.

Prinsip etis dan teologis pekerjaan dikemukakan oleh Malcom Brownlee dengan dua hal yakni pertama, Allah adalah Tuhan atas segala pekerjaan, karena itu bekerja harus dimaknai sebagai persembahan kepada Tuhan. Kedua, Tuhan bekerja dalam setiap bagian kehidupan kita karena itu Dia menunut setiap pekerjaan orang percaya untuk memuliakan

${ }^{28}$ Malcom Brownlee, Tugas Manusia Dalam Dunia: Dasar Teologis Bagi Pekerjaan Orang Kristen Dalam Masyarakat (Jakarta: BPK Gunung Mulia, 2004), 19. 
namaNya. ${ }^{29}$ Jadi secara etis teologis pekerjaan adalah pelayanan yang memuliakan nama Tuhan.

Keseimbangan pekerjaan dan keluarga secara etis dan teologis sangat tergantung kepada pemahaman yang dimiliki hamba Tuhan, keluarga tidak boleh ditelantarkan untuk tujuan pekerjaan atau pelayanan. Khusus secara etis ini menyangkut tatanan nilai etika dalam keseimbangan pelayanan (pekerjaan) dengan keluarga. Dengan berpedoman kepada tugas dan fungsi keluarga yang harus dikedepankan, maka tidaklah elok jika pekerjaan melalaikan kehidupan keluarga.

Rasul Paulus adalah sosok tokoh Alkitab yang dapat dijadikan teladan dalam menjaga keseimbangan pelayanan dengan pekerjaan. Paulus memahami bahwa tugas pekerjaan tidak bisa dipisahkan dari pelayanan, disatu sisi ia harus melakukan pelayanan yang padat, namnun untuk mensupport pelayanan, ia harus bekerja. Dari perspektif Paulus tidak serta merta terkait dengan keseimbangan pelayanan dengankeluarga, namun memberikan esensi bagaimana menjamin keseimbangan. Dalam konteks keseimbangan pekerjaan dengan keluarga, diperlukan pemahaman yang luas tentang pekerjaan itu yakni harus dilakukan dengan kemandirian yang baik (2 Kor 11:9; 1 Tes 3:8), pekerjaan juga sebagai penopang bagi pemberitaan Injil. ${ }^{30}$ Dikotomi pekerjaan dan keluarga harus dihindari, mana yang lebih penting dan bermanfaat, demikian juga tidak boleh menciptakan pemisahan, termasuk memberi standar dan ukuran rohani dan tidak rohani. Yang baik dan tepat adalah memandang keduanya secara proporsional berdasarkan persepsi yang alkitabiah.

Dalam persektif psikologis upaya untuk membangun work balance harus dimulai dengan kesadaran memahami fungsi dan tujuan pekerjaan. Jika fungsi dan tujuan pekerjaan hanya untuk memenuhi basic needs maka cenderung akan melupakan keseimbangan dengan keluarga, namun jika pekerjaan dimaknai sebagai aktualisasi diri maka keseimbangan akan mampu diwujudukan,

Bagi hamba Tuhan (pendeta, gembala, dosen) upaya mengembangkan aktualisasi diri hendaknya memerhatikan aspek psikologis dalam kaitan hubungan sosial utamanya dalam keluarga dan orang lain. Keseimbangan pekerjaan dengan keluarga dapat dilakukan dengan memahami bahwa keduanya sama pentingnya. Pekerjaan untuk keluarga, demikian juga keluarga untuk pekerjaan, dengan pola ini maka para hamba Tuhan akan secara dewasa memposisikan kedua hal tersebut..

Penelitian Muliawati menjelaskan bahwa keseimbangan kerja berhubungan dengan kebutuhan pribadi dan keluarga, dijelaskan bahwa formasi keseimbangan waktu dengan

\footnotetext{
${ }^{29}$ Ibid, 23.

${ }^{30}$ Suwarto Adi, "Kewirausahaan Dan Panggilan Kristen: Sebuah Pendekatan Interpretatif-Dialogis,
} Sosio-Historis Dan Teologis," Kurios: Jurnal Teologi dan Pendidikan Agama Kristen Vol 6, No. 1 (2020): 18. 175 | Copyright $@$ 2020, CARAKA, ISSN 2722-1407 (Cetak), 2722-1393 (Online) 
kebutuhan pribadi dan keluarga memberikan dampak pada produktivitas. ${ }^{31}$ Aspek psikologis seorang yang bekerja didukung kenyamanan, suasana kerja dan juga kebermaknaan pekerjaan akan mampu meningkatkan produktivitas. Hal yang sama juga terjadi kepada para hamba Tuhan, secara psikologis kemanfaatan pekerjaan (pelayanan), akan menyumbang kemampuan berkarya dengan baik. Ini akan berpengaruh bagi kemampuan mewujdukan keseimbangan pekerjaan dan keluarga,

Perspektif manajemen upaya menciptakan keseimbangan pekerjaan dengan keluarga dapat dilakukan dengan beberapa hal: Pertama, pengaturan tanggung jawab dengan tepat. Pada point ini dibutuhkan skill yang baik menata peran atau tugas di kantor dan pelayanan serta peran di rumah. Hamba-hamba Tuhan yang melayani secara aktif apakah full time atau part time dituntut dengan standart dan capaian kerja yang terukur. Pekerjaan dan tanggung jawab dalam keluarga membutuhkan waktu yang sama pentingnya, ini sering berbenturan secara pengaturan waktu. Untuk mengatasi masalah ini dilakukan pembagian tanggung jawab kepada anggota keluarga. Hamba Tuhan harus melakukan dan memiliih mana yang mayor dan minor, jika harus memilih pekerjaan atau pelayanan pilihlah yang memiliki resiko yang lebih kecil.

Kedua, perencanaan agenda keluarga dengan baik. Tujuan perencanan agenda keluarga meminimalisasi persoalan atau tarik menarik kepentingan antara pekerjaan dan keluarga. Dengan merancang agenda keluarga, berbenturan dengan tugas kantor atau sebaliknya dapat dihirndari. Manajemen pengaturan dan perencanaan menjadi sangat prinsip dilakukan oleh para hamba Tuhan. Hal lain dapat juga dilakukan dengan menciptakan quality time bagi keluarga caranya menggunakan waktu akhir pekan untuk acara-acara keluarga, bermain bersama, atau rekreasi bersama, dll. Bagi hamba Tuhan yang ada di perkotaan pilihan agenda keluarga selain diakhir pekan dapat juga memanfaatkan hari-hari libur.

Ketiga, membuat skala prioritas. Tuntutan membuat skala prioritas adalah prinsip yang mampu menanggulangi persoalan keseimbangan kerja. Jika hamba Tuhan memprioritaskan keluarga maka mereka akan memberi waktu dan perhatian lebih untuk anak-anak dan keluarga, sebaliknya jika tidak maka bisa jadi keluarga dilalaikan. Kedua bagian ini sangatlah penting, jadi yang dapat dilakukan yakni menata, mengelola dan mengatur sesuai prioritas.

Dalam hal membuat skala prioritas langkah yang dapat ditempuh antara lain : (1) membuat agenda kerja yang terkait dengan keluarga dan pekerjaan; (2) membuat urutan kegiatan yang telah dijadwalkan; (3) membuat sistem pengingat (reminder) bagi hamba Tuhan

${ }^{31}$ Tryana Muliawati, "Peran Work Life Balance Dan Kepuasan Kerja Terhadap Kinerja Karyawan Milenial: Studi Literatur,” Jurnal Ilmu Manajemen (JIM) Vol 8, No. 2 (2020): 606. 
untuk komitmen keseimbangan kerja dengan keluarga. Ini bisa dengan cara menggunakan aplikasi sebagai toolsnya. ${ }^{32}$

Keempat, melakukan pengelolaan tugas dan fungsi secara akurat. Seorang hamba Tuhan (pendeta,dosen,guru) harus mampu mengelola dimensi tugas yang beragam pada tempat yang beragam pula. Pengelolaan tugas ini bertujuan untuk mengatur porsi tugas secara proporsional, misalnya pendeta yang bertugas melayani mampu mengelola kegiatan gereja dengan rumah dengan baik. Dengan prinsip mengelola dan juga manajemen sebagai seni mendelegasikan tugas, maka tugas-tugas pun dapat didelegasikan. Hamba Tuhan harus mampu menolak agenda-agenda yang padat dan berbenturan dengan kegiatan keluarga, pengecualian kepada hal-hal yang sifatnya emergency.

Hal lain yang dapat dilakukan menata keseimbangan pelayanan dan keluarga yakni dengan memberin nilai tambah bagi keluarga. Dalam hal ini salah satu cara yang bisa ditempuh yakni dengan menjadikan pekerjaan sebagai sarana memberkati orang lain. Apa yang didapatkan melalui pekerjaan (pelayanan) hendaknya menjadi tools menolong orang lain. Hamba Tuhan dapat melakukan added values dengan memberkati jemaat-jemaat yang dilayani. Beberapa cata misalanya memberkati pelayanan misi, menopang masyarakat yang miskin, menolong jemaat yang berkekurangan, dll. Metode added values akan membawa pengaruh bagi anggota keluarga memberi pemahaman bahwa hasil pekerjaan bukan hanya dinikmati keluarga melainkan sarana dan alat berkat bagi orang lain.

\section{KESIMPULAN}

Masalah keseimbangan pekerjaan dan keluarga menjadi pergumulan yang mendasar bagi semua lini kehidupan secara khusus hamba Tuhan (pendeta, dosen, gembala). Ketidakseimbangan dalam menjalankan tugas dan fungsi dalam dua hal ini tentu akan berakibat buruk bagi pelayanan atau keluarga. Para hamba Tuhan didorong untuk menyeimbangkan tugas pelayanan dan keluarga, sehingga keduanya berjalan secara harmonis. Pola yang dilakukan melalui pengelolaan waktu, tugas, fungsi dan tanggung jawab secara seimbang.

Upaya keseimbangan pekerjaan dan keluarga bagi hamba Tuhan dapat diusahakan dengan penataan diri yang lebih dewasa dalam tanggung jawab melalui pemahaman bahwa pekerjaan dan keluarga tugas yang sama pentingnya, tidak terpisahkan, juga tidak hanya mengutamakan satu diantaranya dan mengabaikan lainnya. Intisari keseimbangan dilakukan dengan implementasi tanggung jawab melalui penataan, pengelolaan dan penentuan prioritas

\footnotetext{
${ }^{32}$ Nadiarani Anindita, Lidia Maasir, and Stia Lan Bandung, "Work Life Balance (WLB) Melalui Penerapan Aplikasi Kerja Berbasis IT Pada Pegawai Wanita," Konferensi Nasional Ilmu Administrasi 3, no. 1 (2019): 1 .
} 
bagi pekerjaan dan keluarga. Dengan kedewasan bertindak dan berprilaku, serta dibarengi implementasi nilai-nilai etis dan teologis, seorang hamba Tuhan mampu menyeimbangkan keluarga dan pekerjaan (pelayanan).

\section{REKOMENDASI}

Keseimbangan pekerjaan dengan keluarga merupakan impian setiap hamba Tuhan (pendeta, gembala, dosen) hal ini akan saling mempengaruhi secara positif tugas-tugas pelayanan maupun tanggung jawab bagi keluarga. Keluarga akan menjadi utuh jika para hamba Tuhan mampu menyelaraskan secara proporsional menempatkan pekerjaan (pelayanan) tanpa menelantarkan keluarga. Saran penelitian lebih lanjut terkait keseimbangan keluarga dan pekerjaan, menganalisis hamba Tuhan yang secara penuh waktu melayani dan menggembalakan. Penelitian juga dapat dianalisis berdasarkan lama pelayanan dan berkeluarga.

\section{DAFTAR PUSTAKA}

Anindita, Nadiarani, Lidia Maasir, and Stia Lan Bandung. "Work Life Balance (WLB) Melalui Penerapan Aplikasi Kerja Berbasis IT Pada Pegawai Wanita." Konferensi Nasional Ilmu Administrasi Vol 3, No. 1 (2019): $1-6$.

Brownlee, Malcom. Tugas Manusia Dalam Dunia: Dasar Teologis Bagi Pekerjaan Orang Kristen Dalam Masyarakat. Jakarta: BPK Gunung Mulia, 2004.

Budianto, Agung, Yonathan Pongtuluran, and Syaharuddin Y. "Pengaruh Etika Kerja, Motivasi Kerja Dan Kompensasi Finansial Terhadap Kinerja Karyawan.” KINERJA Vol 14, No. 1 (January 9, 2018): 1-15.

Dominggus, Dicky. "Pengabdian Abdi Dalem Keraton Yogyakarta Sebagai Potret Pelayanan Masa Kini." Voice of Hami 2, no. 2 (2020): 78-93.

Ezra, Tari, and Purnama Pasande. "Etika Kerja Profesional Berdasarkan 2 Kor 2:15-16." Jurnal Gamaliel : Teologi Praktika 1, no. 2 (September 2019): 86-92.

Grzywacz, J. G., and N. F. Marks. "Reconceptualizing the Work-Family Interface: An Ecological Perspective on the Correlates of Positive and Negative Spillover between Work and Family." Journal of occupational health psychology 5, no. 1 (2000): 111-126. Hadinoto, N K Atmaja. Dialog Dan Edukasi Agama Kristen Dalam Masyarakat Indonesia. Jakarta: BPK Gunung Mulia, 2012.

Hairina, Yulia, and Mahdia Fadhila. "Strategi Work-Family Balance Pada Perempuan Suku Banjar Yang Memiliki Peran Ganda." Jurnal Studia Insania 6, no. 2 (2019): 184-192.

Handayani, Arri. "Keseimbangan Kerja Keluarga Pada Perempuan Bekerja: Tinjauan Teori Border." Bulletin Psikologi 21, no. 2 (2012): 90-101.

Handayani, Arri, Tina Afiati, and M G Adiyanti. Studi Eksplorasi Makna Keseimbangan Kerja Keluarga Pada Ibu Bekerja, 2015.

Hartono, Handreas. "Membentuk Karakter Kristen Pada Anak Keluarga Kristen." KURIOS: Jurnal Teologi dan Pendidikan Agama Kristen 2, no. 1 (2014): 62.

Iwamony, Rachel. "Cinta Kasih Sebagai Dasar Hidup Keluarga." Tifa Teologi: Jurnal Pascasarjana Teologi Universitas Kristen Indonesia Maluku 3, no. 1 (2014): 43-74. Latupeirissa, Jacky. "Etika Bisnis Ditinjau Dari Perspektif Alkitab." PASCA : Jurnal Teologi dan Pendidikan Agama Kristen 15, no. 1 (November 30, 2019): 8-15. 
Manggaharti, Retno, and Nur Pratiwi Noviati. "Keseimbangan Kehidupan Kerja Ditinjau Dari Dukungan Sosial Pada Pekerja.” Jurnal Studia Insania 7, no. 1 (July 7, 2019): 1.

Mayasari, N M D A. "Efek Moderasi Dukungan Sosial Dalam Hubungan Konflik Pekerjaan Keluarga Dengan Stres Kerja Dosen Wanita Di Fakultas Ekonomi Undiksha.” Jurnal Manajemen 6, no. 1 (2020): 1-7. https://ejournal.undiksha.ac.id/.

Moleong, Lexy L. Metode Penelitian Kualitatif. Bandung: PT Remaja Rosdakarya, 2004.

Muliawati, Tryana. "Peran Work Life Balance Dan Kepuasan Kerja Terhadap Kinerja Karyawan Milenial: Studi Literatur.” Jurnal Ilmu Manajemen (JIM) 8, no. 2 (2020): 606619.

Putri, Thalia Febiola, and Yenny Sugiarti. "Work-Life Balance Konsultan Pajak Di Kantor Konsultan 'X' Di Surabaya.” Akuntansi dan Teknologi Informasi 13, no. 1 (2020): 1-15.

Rizky Adhani, Akbar. "Pengaruh Kebutuhan Aktualisasi Diri Dan Beban Kerja Terhadap Prestasi Kerja Karyawan.” Jurnal Ilmu Manajemen (JIM) 1, no. 4 (2013): 1223-1233.

Silalahi, Junior Natan. "Paulus Sang Entrepreneur: Pembuat Tenda Sebagai Jembatan Penginjilan." Visio Dei: Jurnal Teologi Kristen 1, no. 1 (2019): 1-18.

Sugiyono. Metode Penelitian Kualitatif. Bandung: Alfabeta, 2009.

Suwarto Adi. "Kewirausahaan Dan Panggilan Kristen: Sebuah Pendekatan InterpretatifDialogis, Sosio-Historis Dan Teologis." Kurios: Jurnal Teologi dan Pendidikan Agama Kristen 6, no. 1 (2020): 18-34.

Tari, Ezra, and Talizaro Tafonao. "Pendidikan Anak Dalam Keluarga Berdasarkan Kolose 3:21." Kurios: Jurnal Teologi dan Pendidikan Agama Kristen 5, no. 1 (April 30, 2019): $24-35$. 